\title{
Hematological Profile of Untreated or Ionizing Radiation-Exposed Cyclooxygenase-2-Deficient Mice
}

\author{
M. HOFER ${ }^{1}$, Z. HOFEROVÁ ${ }^{1}$, L. DUŠEK ${ }^{2}$, K. SOUČEK $^{3,4,5}$, A. GRUZDEV $^{6}$ \\ ${ }^{1}$ Department of Molecular Cytology and Cytometry, Institute of Biophysics of the Czech Academy \\ of Sciences, Brno, Czech Republic, ${ }^{2}$ Institute of Biostatistics and Analyses, Faculty of Medicine, \\ Masaryk University, Brno, Czech Republic, ${ }^{3}$ Department of Cytokinetics, Institute of Biophysics of \\ the Czech Academy of Sciences, Brno, Czech Republic, ${ }^{4}$ International Clinical Research Center, \\ St. Anne's University Hospital, Brno, Czech Republic, ${ }^{5}$ Department of Experimental Biology, \\ Faculty of Science, Masaryk University, Brno, Czech Republic, ${ }^{6}$ Laboratory of Respiratory \\ Biology, Division of Intramural Research, NIEHS/NIH, Research Triangle Park, NC, USA
}

Received December 8, 2016

Accepted January 25, 2017

On-line April 12, 2017

\section{Summary}

We investigated hematopoiesis in untreated and ionizing radiation-exposed cyclooxygenase-2-deficient (COX-2 KO) mice. We performed a complex hematological analysis of 16 parameters in untreated $\mathrm{COX}-2 \mathrm{KO}$ male mice or COX-2 $\mathrm{KO}$ male mice irradiated with the dose of $4 \mathrm{~Gy}$ of $\mathrm{y}$-rays and their wildtype littermates. At baseline, hematopoiesis was increased in cOX-2-deficient mice, but attenuated by irradation in cOX-2deficient mice compared to wildtype. To conclude, the antiinflammatory action of the COX-2 genetic disruption plays a positive role in hematopoiesis under basal conditions but is detrimental following radiation exposure.
\end{abstract}

\section{Key words}

Cyclooxygenase-2 • COX-2 knock-out mice - Hematopoiesis • Ionizing radiation • Post-irradiation inflammation

\section{Corresponding author}

M. Hofer, Department of Molecular Cytology and Cytometry, Institute of Biophysics of the Czech Academy of Sciences, Královopolská 135, CZ-61265 Brno, Czech Republic. Fax: +420/541211293. E-mail: hofer@ibp.cz

\section{Introduction}

Previously, we tested hematological effects of meloxicam, an anti-inflammatory drug and a selective
COX-2 inhibitor (Carrabba et al. 1995), and we observed stimulation of hematopoiesis and improved post-irradiation survival in meloxicam-treated animals (Hofer et al. 2006, Hofer et al. 2008a,b, Hofer et al. 2011). In this study, we used cyclooxygenase-2-deficient (COX-2 KO) mice for hematological examinations under basal conditions and following radiation-induced myelosuppression. Loss of COX-2 activity in the COX-2 KO mice is chronic, absolute, and selective, while pharmacological COX-2 inhibition is acute, potentially not absolute, and may result in non-selective coinhibition of cyclooxygenase-1 (Patrignani and Patrono 2015). This is why an analysis of hematopoiesis in COX-2 KO mice can give new knowledge on the regulatory role of COX-2 in the hematopoietic system.

\section{Methods}

Mice

10-week-old male COX-2-deficent and wildtype littermates on a 129B6F1 genetic background were used (Morham et al. 1995). The use and treatment of the animals followed the European Community Guidelines. The experiments were approved by the Institute's Ethical Committee. 


\section{Irradiation}

The mice were whole-body irradiated at a dose rate of $0.34 \mathrm{~Gy} / \mathrm{min}$ using a $\gamma$-ray source $\left({ }^{60} \mathrm{Co}\right.$, Chisostat, Chirana, Prague, Czech Republic).

\section{Hematological methods}

The animals were anesthetized with an i.p. injection of a Narkamon/Rometar (Spofa, Prague, Czech Republic). The peripheral blood was collected by cardiac puncture. The values of total leukocytes, neutrophils, lymphocytes, erythrocytes, and platelets per $1 \mu \mathrm{l}$ of the peripheral blood, blood hemoglobin level, hematocrit, mean erythrocyte volume, mean erythrocyte hemoglobin, mean erythrocyte hemoglobin concentration, mean platelet volume, and plateletcrit were determined by an Auto Hematology Analyzer Mindray 5300Vet (Shenzen, China). The numbers of femoral nucleated cells were determined by a Coulter Counter (Model ZF, Coulter Electronics, Luton, UK). Granulocyte-macrophage and erythroid colony-forming cells (GM-CFC and BFU-E, respectively), were assessed using MethoCult M3001 and MethoCult SF M3436, respectively (Stem Cell Technologies, Vancouver, Canada) (Hofer et al. 2015).

\section{Statistics}

The experiments were performed twice and their results were combined. Statistical significance of the differences between WT and COX-2 KO mice were tested by Mann-Whitney U test.

\section{Results}

The values of 16 parameters of the peripheral blood, bone marrow and spleen in untreated COX-2 KO (cyclooxygenase-2-deficient) mice or COX-2 KO mice irradiated with a sublethal dose of 4 Gy of $\gamma$-rays, and in WT (wild-type) mice are shown in Table 1.

It follows from the findings that the genetic disruption of COX-2 has different effects in the hematopoietic system in basal conditions and following exposure to a sublethal radiation dose. In untreated mice, 4 parameters were significantly higher and none were significantly lower in COX-2 KO mice compared to WT mice. In irradiated mice, 4 parameters were significantly lower and of none were significantly higher in COX-2 KO mice compared to WT mice (Table 1).

In 14 out of the 16 hematological parameters shown, the values in COX-2 KO mice could be expressed as per cent of those in the WT mice in both the untreated and irradiated animals; blood neutrophils and lymphocytes could not be determined in irradiated mice. In 11 out of 14 parameters accessible in this way, this value in irradiated mice was lower compared to that in the untreated ones (Table 1).

\section{Discussion}

Radiation-induced inflammation is a long known and widely studied phenomenon (Schaue et al. 2015). The bone marrow radiation syndrome, which has been induced in this study by the dose of 4 Gy of $\gamma$-rays, is naturally accompanied by manifestations of an acute inflammation (Casey-Sawicki et al. 2014). This communication is the first attempt to use COX-2 KO mice for the evaluation of the effects of COX-2 genetic disruption on hematopoiesis under both basal conditions and following a sublethal radiation exposure. The lifelong loss of the COX-2 activity in the COX-2 KO mice should produce a permanent anti-inflammatory effect.

These initial results on this topic do not allow for detailed analyses and conclusions. However, a basic inference can be made from the findings obtained: whereas in untreated COX-2 $\mathrm{KO}$ mice, the antiinflammatory effects of chronic COX-2-deficiency positively affect hematopoiesis, the opposite is true in irradiated COX-2-deficient mice. As concerns the postirradiation conditions, the findings in this study differ from those previously obtained following acute pharmacological COX-2 inhibition (Hofer et al. 2006, Hofer et al. 2008a,b, Hofer et al. 2011) where stimulation of hematopoiesis was observed following administration of a selective COX-2 inhibitor.

The observed decline in the numbers of hematopoietic progenitor cells in the bone marrow of the irradiated COX-2 KO mice suggests that also numbers of the peripheral blood neutrophils, which are important for the evaluation of the inflammatory status in these animals, should be decreased in the irradiated COX-2deficient mice. Due to the very low levels of the total blood leukocytes in the irradiated mice, not enabling to determine the neutrophil numbers (see the legend to Table 1), their values, as well as the values of their subpopulations, including neutrophils, will be determined by another method, e.g. by flow-cytometry, in the subsequent study. 
Table 1. Values of hematological parameters in untreated and 4 Gy-irradiated mice.

\begin{tabular}{|c|c|c|c|c|}
\hline Parameter & $\begin{array}{l}\text { Untreated } \\
\text { WT mice } \\
(n=7)\end{array}$ & $\begin{array}{c}\text { Untreated } \\
\text { COX-2 KO mice } \\
\qquad(n=7)\end{array}$ & $\begin{array}{c}4 \text { Gy-irradiated } \\
\text { WT mice } \\
(n=8)\end{array}$ & $\begin{array}{c}4 \text { Gy-irradiated } \\
\text { COX-2 KO mice } \\
(n=7)\end{array}$ \\
\hline Blood leukocyte count $\left(x 10^{9} / l\right)^{@}$ & $3.01 \pm 0.40$ & $\begin{array}{c}4.66 \pm 0.70 \\
(155 \%)\end{array}$ & $0.36 \pm 0.02$ & $\begin{array}{l}0.47 \pm 0.05 \\
(131 \%)\end{array}$ \\
\hline Blood neutrophil count $\left(x 10^{9} / l\right)$ & $0.71 \pm 0.15$ & $2.33 \pm 0.59^{\#}$ & ND & ND \\
\hline Blood lymphocyte count $\left(x 10^{9} / l\right)$ & $2.24 \pm 0.35$ & $2.07 \pm 0.11$ & ND & ND \\
\hline Blood erythrocyte count $\left(x 10^{12} / l\right)^{@}$ & $9.10 \pm 0.13$ & $\begin{array}{l}8.89 \pm 0.45 \\
(98 \%)\end{array}$ & $8.07 \pm 0.14$ & $\begin{array}{l}7.70 \pm 0.27 \\
(95 \%)\end{array}$ \\
\hline Blood hemoglobin level $(H G B)(g / l)^{@}$ & $137.3 \pm 1.2$ & $\begin{array}{c}132.0 \pm 5.7 \\
(96 \%)\end{array}$ & $123.7 \pm 1.4$ & $\begin{array}{c}116.4 \pm 3.8 \\
(94 \%)\end{array}$ \\
\hline Hematocrit (HCT) (\%) & $45.6 \pm 0.4$ & $\begin{array}{c}43.9 \pm 1.7 \\
\quad(96 \%)\end{array}$ & $40.5 \pm 0.6$ & $\begin{array}{c}38.1 \pm 1.2 \\
(94 \%)\end{array}$ \\
\hline Mean erythrocyte volume $(M C V)(f l)^{@}$ & $50.9 \pm 0.2$ & $\begin{array}{c}50.5 \pm 1.3 \\
(99 \%)\end{array}$ & $50.8 \pm 0.2$ & $\begin{array}{c}49.4 \pm 0.4^{* *} \\
(97 \%)\end{array}$ \\
\hline Mean erythrocyte hemoglobin (MCH) (pg) ${ }^{@}$ & $15.3 \pm 0.1$ & $\begin{array}{c}15.1 \pm 0.3 \\
(99 \%)\end{array}$ & $15.5 \pm 0.1$ & $\begin{array}{l}15.1 \pm 0.1^{* *} \\
(97 \%)\end{array}$ \\
\hline $\begin{array}{l}\text { Mean erythrocyte hemoglobin } \\
\text { concentration }(\mathrm{MCHC})(\mathrm{g} / \mathrm{l})\end{array}$ & $301.2 \pm 1.7$ & $\begin{array}{c}300.1 \pm 1.8 \\
(100 \%)\end{array}$ & $305.4 \pm 1.3$ & $\begin{array}{l}305.8 \pm 0.9 \\
\quad(100 \%)\end{array}$ \\
\hline Blood platelet count $\left(x 10^{9} / l\right)$ & $897.4 \pm 37.7$ & $\begin{array}{l}1008.2 \pm 57.4 \\
\quad(112 \%)\end{array}$ & $906.2 \pm 55.1$ & $\begin{array}{c}1038.0 \pm 109.0 \\
(114 \%)\end{array}$ \\
\hline Mean platelet volume $(f l)^{@}$ & $4.53 \pm 0.04$ & $\begin{array}{l}4.70 \pm 0.02^{\# \#} \\
\quad(104 \%)\end{array}$ & $4.51 \pm 0.04$ & $\begin{array}{c}4.52 \pm 0.04 \\
(100 \%)\end{array}$ \\
\hline Plateletcrit (\%) & $0.41 \pm 0.02$ & $\begin{array}{l}0.47 \pm 0.03 \\
(115 \%)\end{array}$ & $0.41 \pm 0.02$ & $\begin{array}{l}0.47 \pm 0.05 \\
\quad(115 \%)\end{array}$ \\
\hline $\begin{array}{l}{ }^{1} \text { Femoral bone marrow cellularity/g body } \\
\text { weight }\left(x 10^{3}\right)^{@}\end{array}$ & $0.95 \pm 0.02$ & $\begin{array}{c}1.00 \pm 0.02 \\
(105 \%)\end{array}$ & $0.27 \pm 0.01$ & $\begin{array}{c}0.21 \pm 0.01 * * \\
(78 \%)\end{array}$ \\
\hline${ }^{I} G M-C F C /$ femur/g body weight ${ }^{@}$ & $495.9 \pm 13.7$ & $\begin{array}{c}565.2 \pm 18.78^{\# \#} \\
(114 \%)\end{array}$ & $77.0 \pm 8.5$ & $\begin{array}{c}58.8 \pm 5.7 \\
(76 \%)\end{array}$ \\
\hline${ }^{1} B F U-E /$ femur/g bodyweight ${ }^{@}$ & $505.0 \pm 33.9$ & $\begin{array}{c}579.1 \pm 20.2 \\
(115 \%)\end{array}$ & $60.1 \pm 3.8$ & $\begin{array}{c}40.3 \pm 6.3^{*} \\
(67 \%)\end{array}$ \\
\hline${ }^{I}$ Spleen weight/g body weight $(g)^{@}$ & $2.62 \pm 0.19$ & $\begin{array}{c}5.53 \pm 1.10^{\# \# \#} \\
(211 \%)\end{array}$ & $1.59 \pm 0.11$ & $\begin{array}{c}1.95 \pm 0.17 \\
(123 \%)\end{array}$ \\
\hline
\end{tabular}

The results are presented as arithmetic means \pm standard errors of the means (SEM). $n$ - numbers of mice. ${ }^{1}-$ considering the differences in the average body weight between the groups of mice studied (results not shown), the values of the bone marrow parameters and that of the spleen weight were expressed as per $1 \mathrm{~g}$ of body weight. ND - not done (the analyzer used allows to determine numbers of neutrophils and lymphocytes only when the total leukocyte number exceeds the value of $\left.0.5 \times 10^{9} / \mathrm{l}\right)$. \#, \#\#, \#\#\# - value in COX-2 KO mice is statistically significantly higher ( $\mathrm{P} \leq 0.05, \mathrm{P} \leq 0.01, \mathrm{P} \leq 0.001$, respectively) than that in the corresponding WT counterparts. $*, * *-$ value in COX-2 KO mice is statistically significantly lower ( $P \leq 0.05, P \leq 0.01$, respectively) than that in the corresponding WT counterparts. ${ }^{@}$ - value of the pertinent parameter in COX-2 KO mice, expressed as per cent of that in respective WT mice, is lower in irradiated animals. 
To conclude, it seems that radiation-induced inflammation results in stimulation of hematopoiesis in the irradiated mice; consequently, the chronic anti-inflammatory effects of COX-2 genetic disruption in the COX-2 KO mice cause hematopoiesis-suppressing action in the post-irradiation conditions. Further studies are needed to obtain more data on hematopoiesis in radiation-exposed COX-2 $\mathrm{KO}$ mice and on how hematopoietic processes in these mice are reflected in their post-irradiation survival. The results of the survival studies should also show whether the expected radiation damage to the gastrointestinal tissues evoked with high radiation doses can be influenced in the COX-2 $\mathrm{KO}$ mice in which the production of cyclooxygenase-1, important for the gastrointestinal tract, should be preserved.

\section{Conflict of Interest}

There is no conflict of interest.

\section{Acknowledgements}

This work was supported by project no. LQ1605 from the National Program of Sustainability II (MEYS CR), by the European Union - project ICRC-ERA-HumanBridge (No. 316345), and from the Czech Science Foundation (grant No. 16-1245S).

\section{References}

CARABBA M, PARESCE E, ANGELINI M, GALANTI A, MARINI MG, CIGARINI P: A comparison of the local tolerability, safety and efficacy of meloxicam and piroxicam suppositories in patients with osteoarthritis: a single blind, randomized, multicentre study. Curr Med Res Opin 13: 343-355, 1995.

CASEY-SAWICKI K, ZHANG M, KIM S, ZHANG A, ZHANG SB, ZHANG ZH, SINGH R, YANG SM, SWARTS S, VIDYASAGAR S, ZHANG LR, ZHANG AG, OKUNIEFF P: A basic fibroblast growth factor analog for protection and mitigation against acute radiation syndromes. Health Phys 106: 704-712, 2014.

HOFER M, POSPÍŠIL M, ZNOJIL V, HOLÁ J, VACEK A, WEITEROVÁ L, ŠTREITOVÁ D, KOZUBÍK A: Meloxicam, a cyclooxygenase-2 inhibitor, supports hematopoietic recovery in gamma-irradiated mice. Radiat Res 166: 556-560, 2006.

HOFER M, POSPÍŠIL M, HOLÁ J, VACEK A, ŠTREITOVÁ D, ZNOJIL V: Inhibition of cyclooxygenase 2 in mice increases production of G-CSF and induces radioprotection. Radiat Res 170: 566-571, $2008 \mathrm{a}$.

HOFER M, POSPÍŠIL M, ZNOJIL V, HOLÁ J, VACEK A, ŠTREITOVÁ D: Meloxicam, an inhibitor of cyclooxygenase-2, increases the level of serum G-CSF and might be usable as an auxiliary means in G-CSF therapy. Physiol Res 57: 307-310, 2008b.

HOFER M, POSPÍŠIL M, DUŠEK L, HOFEROVÁ Z, WEITEROVÁ L: A single dose of an inhibitor of cyclooxygenase 2, meloxicam, administered shortly after irradiation, increases survival of lethally irradiated mice. Radiat Res 176: 269-272, 2011.

HOFER M, POSPÍŠIL M, DUŠEK L, HOFEROVÁ Z, KOMU゚RKOVÁ D: Hematopoiesis in 5-fluorouracil-treated adenosine $\mathrm{A}_{3}$ receptor knock-out mice. Physiol Res 64: 255-262, 2015.

MORHAM SG, LANGENBACH R, LOFTIN CD, TIANO HF, VOULOUMANOS N, JENNETTE JC, MAHLER JF, KLUCKMAN KD, LEDFORD A, LEE CA, SMITHIES O: Prostaglandin synthase 2 gene disruption causes severe renal pathology in the mouse. Cell 83: 473-482, 1995.

PATRIGNANI P, PATRONO C: Cyclooxygenase inhibitors: from pharmacology to clinical read-outs. Biochim Biophys Acta 1851: 422-432, 2015.

SCHAUE D, MICEWICZ ED, RATIKAN JA, XIE MW, CHENG GH, MCBRIDE WH: Radiation and inflammation. Semin Radiat Oncol 25: 4-10, 2015. 